\title{
The study program open to new societal needs and challenges of the labour market - on the example of the project "Career guidance open to ecological awareness development of a society"
}

\author{
Kulpa-Puczyńska, Aleksandra \\ Cardinal Stefan Wyszyński University in Warsaw
}

\begin{abstract}
The aim of the study (poster) is primarily to present assumptions, current results and possible directions for further research and practices related to project implementation titled "Career guidance open to ecological awareness development of a society" [in Polish: Poradnictwo zawodowe otwarte na ksztattowanie świadomości ekologicznej społeczeństwa] (FSS/2014/HEI/W/0032), financed with the Norwegian funds and domestic funds under the Polish Higher Education Development Programme [Program Rozwój Polskich Uczelni], Scholarship and Training Fund [Fundusz Stypendialny i Szkoleniowy], realized (1/1/2015 - 5/31/2016) at the Department of Pedagogical Sciences of the Cardinal Stefan Wyszyński University (UKSW). The analysis both literature and the currently undertaken research activities, among others, leads to the conclusions that there are at least three important tasks which modern higher education has to face. 1. The promotion of solutions, including educational ones, which aim at limiting the possible risks to human life (deterioration of its quality) resulting from the type of profession and work organization; 2. Active participation of vocational guidance consultants (present and future) in building sustainable and environmentally friendly societies. 3. The necessity of cooperation among local entities (including universities) involved in lifelong vocational guidance. In this context and with reference to the concept of "green" universities and the engaged university concept, the following question also becomes important: What is the role of higher education institutions in shaping pro-environmental attitudes?
\end{abstract}

Keywords: higher education institution, vocational guidance, environmental awareness, labour market, continuous improvement . 


\section{Introduction - from theory to practice}

According to the "Expertise on education for sustainable development in Poland" [in Polish: "Ekspertyza dotycząca edukacji dla zrównoważonego rozwoju w Polsce"], the above-mentioned education is carried out primarily in the form of projects (targeted at schools) by NGOs, Ministry of Environment, local governments and local institutions. Adults are usually educated through children and young people or at the workplace, but still not very often. Thus, in the aforementioned report it is stressed that adult education on sustainable development should be realized in various ways and using a variety of sources, in order to reach as many people as possible (ITTI Consultants Team \& Ministry of Environment, 2012). This recommendation was also taken into account during the planning and implementation of project activities recognized in the present text. Universities are also responsible for popularizing the idea and implementation of the principles of sustainable development, that educate future workers, employers and leaders of social life. The point is also about the opportunity to acquire (during the education process) pro-environmental knowledge and skills necessary for work.

The presented project, titled "Career guidance open to ecological awareness development of a society", fits well in the increasingly popular in Poland engaged university concept, which focuses on the developmental role of a university and its capabilities of adaptation to regional needs. Assuming a more open, but also pro-innovative character of higher education institutions (Goldstein, 2010). The analysed project takes into account the needs of the labour market, it is also an opportunity to create a network of cooperation between local institutions and is an example of an approach to the problem of innovation from the creative process perspective, treating innovation as a set of skills, a different way of organization, synthesis and expression of knowledge, perception of the world and creating new perspectives, reactions and products (Triz, 1997). Therefore, this project aims primarily at: shaping the environmental sensitivity of people participating directly or indirectly in the implementation of vocational guidance services, equipping them with environmental knowledge and the ability to shape pro-environmental attitudes, especially among those who carry out activities aimed at environmental education at school, in extracurricular education institutions and workplaces.

\section{Forms and methods of implementation of the project}

To achieve the above-mentioned results, the framework of the project (the main project coordinator - dr hab. B. Baraniak, prof. UKSW) included two-semester postgraduate studies on "Career guidance open to ecological awareness development of a society". Their program (authors: prof. B. Baraniak, prof. D. Cichy) - established on the basis of educational results approved by the University Senate (Resolution No. 166/2014) includes content dealing with pro-environmental attitudes, entered in the content of 
professional advice directed, among others, to students pursuing educational and professional decisions, job seekers and also employers and employees, open to the knowledge of sustainable development. As a result, the study program goes beyond the traditional concept of counselling, stressing the importance of education at the formal, nonformal and informal level (EU Council Resolution, 2008/C 319/02). It also promotes educational and professional counselling, which is bound to assist people in managing their careers and building self-esteem and is designed to provide the knowledge and skills necessary to overcome life's difficulties. Such support should be available at different stages of life, in schools, workplaces, labour market institutions, local communities (OECD \& EC, 2004). Therefore, the study program consists of two thematic modules:

1) Environment in shaping environmental awareness of society (number of hours for the module - 120), including the following subjects realized in the form of lectures and classes: Basics of shaping ecological awareness, Basics of environmental axiology and deontology, Business vs environment, Legal aspects of environmental protection, Culture vs human ecology;

2) Environment in vocational guidance (number of hours for the module - 150), including the following subjects realized in the form of lectures, classes and workshops: Occupational knowledge and vocational guidance methodology in the ecological aspect, Vocational guidance in the popularisation and development of pro-environmental economy including agriculture, Vocational guidance in shaping pro-environmental and pro-health attitudes in the society, Vocational guidance vs pro-environmental attitudes of employees and employers.

The content of the aforementioned subjects includes, among others, the answer to important societal needs (e.g. the development of health self-awareness). Over $70 \%$ of Poles give health as the most important value in their lives, just after family happiness. However, health attitudes for most people are only general declarations (CBOS, 2012). A conscious society, engaged in making deliberate choices in different areas of life - as basic units of the society, professional groups and local governments - is a prerequisite of directing a country towards a sustainable way of development. In "The Strategy for Sustainable Development of Poland until 2025" [in Polish: "Strategia Zrównoważonego Rozwoju Polski do 2025 roku"] we read also that educational programs should promote values and life-styles other than those consumption-oriented (Ministry of Environment, 1999). This is what happened in the case of the project studies, including e.g. the problem of achieving well-being at work, motivational programs concerning changing the organization of work or work-life balance. 
On the other hand, the answer to the challenges of modern economies and labour markets are included in the following (discussed during studies) issues: strategies for safe and economical disposal of household waste; responsibility programs to water quality; employment opportunities in pro-environmental occupations; risks occurring in industries and occupations having a negative impact on the environment; solutions that minimize the incidence of occupational diseases, the possibility of effective cooperation among local entities on pro-environmental issues, forms of extracurricular education useful in solving the problems of sustainable development. The syllabi of subjects included issues identified as significant ecological opportunities (decisive works on the transposition of the EU environmental legislation, well-managed public forests) and challenges (limited possibilities for performing an economic analysis of environmental policies, low level of innovation), and are described, among others, in the latest Polish ecological review (OECD, 2015). During the studies, also the following issues were discussed: social and environmental responsibility among companies, eco innovations. At this point it is worth noting that pollution, in the eyes of EU societies, is considered one of the most negative effects of business - after corruption, non-compliance with labour standards and reduction of jobs (Eurobarometer 363, 2013).

Referring to the analysed project it should also be noted that when planning the educational process, it was ensured for the course to be dominated by activating methods (brainstorming, debate, map of associations, working in teams, case studies). Acquainting the participants of the course with the currently undertaken actions aimed at the protection of the environment, including the use of unconventional methods, e.g. utilisation of waste generated from industry or service activities, allowed study visits at employers' premises. This is consistent with the assumption, which at the same time constitutes a specific challenge that environmental education should aim for greater interrelations between the process of teaching and the reality. Post-graduate students (61 people) also take part in the preparation and presentation of group projects - they prepare, among others, proenvironmental solutions in their workplaces or homes and develop a concept for their implementation. Actively conducted courses are not only aimed at sensitizing, moving emotions, but also motivating for further education and self-education, which is what the students have proved with their projects.

\section{The perspective of the development of project activities}

Today, not only educational and vocational guidance, but also education faces an important challenge of promoting specific occupations, labour and its organization, and the implementation of specific plans, strategies and programs that minimize potential risks to human health and life. Therefore, the framework of the project includes the preparation of 
didactic materials dedicated for the e-learning platform and two peer-reviewed publications: "Shaping ecological awareness society. Theory and practice", science editor: prof. dr hab. D. Cichy [in Polish: "Kształtowanie świadomości ekologicznej społeczeństwa. Teoria i praktyka”] and „Vocational guidance in shaping society environmental awareness. From theory to practice", science editor: dr hab. B. Baraniak, prof. UKSW [in Polish: "Poradnictwo zawodowe w kształtowaniu świadomości ekologicznej społeczeństwa. Od teorii do praktyki"]. The authors of elaborations sought primarily to draw attention to environmental risks (at the national and European levels) and the resulting need for shaping environmental awareness among people who determine the level of education, both general and vocational. The developed teaching materials in an electronic format, books, the program of studies - available not only for the participants of the project - will also contribute to a wider promotion of knowledge conveyed during the course.

In addition, it is assumed that the ongoing project will also bring the following benefits:

1) For participants in the project (besides the aforementioned values)

- Workshop scenarios developed during the studies and presented in publications, tools used by today's vocational guidance consultants, as well as forms and methods of education characteristic for modern enterprises will enhance the students' working environment.

- The project reflects the fact that today's employers search for people endowed with the, so called, soft competencies, such as the ability to organize work, work management with regard to the need of minimizing waste - a threat not only to the environment but also the health of employees and their safety at work.

- Increased environmental awareness of the project participants will also translate into their personal actions (concerning the workplace or household) having a positive impact on the environment, as well as their everyday lifestyle.

\section{2) For the university implementing the project}

- Knowledge and skills of the post-graduate students - the knowledge of practitioners with great professional experience e.g. in public employment services, will be utilized through conferences, lectures or workshops.

- The activity of the students of the Department of Pedagogical Sciences at the Cardinal Stefan Wyszyński University in the project allows them to acquire essential skills (organizational, communicational) and establish new professional contacts, it can also help to launch new "green" academic ventures.

- Actions undertaken within the framework of the project are also aimed at increasing knowledge and awareness of the entire university community, concerning the protection of the environment and environmentally friendly jobs. 


\section{3) For external stakeholders}

- Study visits in enterprises are an example of measures aimed at enhancing the cooperation between university and employers - and an opportunity to establish new contacts, which may be useful in the future, e.g. in developing a program or path of education; conducting research, or organizing apprenticeships;

- The potential of the teaching staff and the experience gained in the project can be used and developed during the forthcoming projects: the preparation of new courses, specialization, thereby extending the business offer of the department.

- The conference, expected to be held at the end of the project, will contribute to enhancing institutional cooperation, among others, at all levels of education (both general and vocational), and will include representatives of the labour market.

\section{Conclusion}

Most of the above-mentioned points fit in, primarily, in social and environmental aspects of the awareness of sustainable development. However, we cannot forget about the correlated economic aspect. The adopted by the European Council "Europe 2020" Strategy has identified three interrelated development priorities: 1. Smart growth - economy development based on knowledge and innovation; 2. Sustainable growth - supporting economy being more resource efficient, greener and more competitive and 3 . Inclusive growth - promoting a high-employment economy which delivers social and territorial cohesion (EC, 2010).

In the case of adults it is worth talking about the principles of sustainable development using the language of profit. It should also be ensured that the actions are not just occasional actions, but that they should constitute part of the strategy - e.g. education for sustainable development in all fields of study. Such education at university level should also include: various forms of professional development, popularization of innovative scientific achievements, the search for innovative methods of education and participation in national and international programs, cooperation between universities and learning from the experience of others (Sustainia \& IARU, 2014). Pedagogical education institution can also help popularize the idea of taking pro-environmental actions, e.g. among the cooperating employers, while taking into account the environmental determinants of human capital management models in companies. 


\section{References}

CBOS Public Opinion Research Center (2012). Poles About Their Health, Healthy Behaviors and Activities. Polish Public Opinion. Warsaw. Retrieved January 15, 2016, from http://www.cbos.pl/EN/publications/reports/2012/110_12.pdf

Eurobarometer $363 \quad$ (2013). Retrieved January 15, 2016 from http://ec.europa.eu/public_opinion/archives/flash_arch_374_361_en.htm

European Commission (2010) COMMUNICATION FROM THE COMMISSION EUROPE 2020. A strategy for smart, sustainable and inclusive growth. Brussels.

Goldstein H. A (2010). The 'entrepreneurial turn' and regional economic development mission of universities. Annals of Regional Science, 44 (1), 83-109.

ITTI Consultants Team \& Ministry of Environment (2012). Expertise on education for sustainable development in Poland. The final report [in Polish: Ekspertyza dotycząca edukacji dla zrównoważonego rozwoju w Polsce. Raport końcowy]. Poznań. Retrieved January 15, 2016, from https://www.mos.gov.pl/g2/big/2013_01/5be891622543678831acb68b4d83fa1a.pdf

Ministry of the Environment, Republic of Poland (1999), The Strategy for Sustainable Development of Poland until 2025 [in Polish: Strategia Zrównoważonego Rozwoju Polski do 2025 roku]. Guidelines for ministries developing sectoral strategies. Section 5.5 Education at all levels [in Polish: Część 5.5 "Edukacja na wszystkich poziomach"]. Warsaw.

OECD (2015). OECD Environmental Performance Reviews: Poland 2015, OECD Publishing. Retrieved January 15, 2016, from http://dx.doi.org/10.1787/9789264227385-en

OECD \& European Communities (2004). Career Guidance. A Handbook for Policy Makers. Paris. Retrieved January 15, 2016, from http://www.oecd.org/edu/innovationeducation/34060761.pdf

Resolution of the Council and of the Representatives of the Governments of the Member States, meeting within the Council of 21 November 2008 on better integrating lifelong guidance into lifelong learning strategies (2008/C 319/02).

Resolution No. 166/2014 by the Senate of the Cardinal Stefan Wyszyński University in Warsaw of 18 December 2014 on granting permission to organize and implement postgraduate studies on "Career guidance open to ecological awareness development of a society".

Sustainia and IARU (2014). Green Guide for Universities. IARU pathways towards sustainability. Retrieved January 15, 2016, from http://www.iaruni.org/images/stories/Sustainability/IARU_Green_Guide_for_Universiti es_2014.pdf

The Department of Pedagogical Sciences of the Cardinal Stefan Wyszyński University (2015). Career guidance open to ecological awareness development of a society. Conference Study Materials, editors: B. Baraniak, D. Cichy. Warsaw.

Triz (1997). An Approach to systematic innovation. GOAL/QPC Research Committee. Volume 1 of Research Report, 2. 